\section{Risk factors for reinvasion of human dwellings by sylvatic triatomines in northern Bahia State, Brazil}

\author{
Fatores de risco para re-infestação \\ de domicílios por triatomíneos silváticos \\ no norte do Estado da Bahia
}

Annie Walter 1 Isabel Pojo do Rego 2 Agenor José Ferreira ${ }^{3}$ Christophe Rogier 4

\footnotetext{
1 Laboratoire de Lutte Contre les Insectes Nuisibles, Institut de Recherche pour le Développement (URO16), Paris, France. 2 Departamento de Sociologia, Universidade de Brasília, Brasília, Brasil. 3 15o Diretório Regional de Saúde, Fundação Nacional de Saúde, Brasília, Brasil. 4 Institut de Médecine Tropicale du Service de Santé des Armées, Marseille, France.

Correspondence A. Walter

Laboratoire de Lutte Contre les Insectes Nuisibles, Institut de Recherche pour le Développement. 911, Avenue Agropolis BP 64501 - 34394 Montpellier cedex 5 , Paris, France. walter@mpl.ird.fr
}

\begin{abstract}
The aim of this study in Curaça, Bahia, Northeast Brazil was to explore possible factors associated with the infestation of human dwellings by Triatoma brasiliensis or Triatoma pseudomaculata, two sylvatic triatomine species. We use multiple logistic regression analysis to show how structural features of the peridomiciliary area combine with the number of animals and sociological factors to allow infestation of some dwellings. It is suggested that $\mathrm{T}$. brasiliensis is associated with human activities, while T. pseudomaculata is associated with vegetation and animals. Peridomiciliary farm animals are a strong risk factor for triatomine infestation.
\end{abstract}

Triatominae; Risk Factors; Vector Control

\section{Introduction}

In Northeast Brazil, the main vectors for American trypanosomiasis are currently Triatoma brasiliensis and Triatoma pseudomaculata, two widely distributed native species. They are captured in domiciliary and peridomiciliary areas which they reinvade from natural ecotopes 1 . The potential for re-infestation of peridomiciliary annexes is high 2 . Both of these vectors lodge in corral fences, chicken coops, and piles of various materials found in and around numerous buildings in this farming and livestock area $3,4,5$. However, the joint effects of peridomiciliary structural features, the number of synanthropic animals, and sociological factors on domiciliary infestation are still not well known.

In order to broaden the knowledge on risk factors for peridomiciliary re-infestation by sylvatic triatomines, the objective of this study was to assess the main characteristics of dwellings (environmental, demographic, and socioeconomic factors are the independent variables) associated with T. brasiliensis or T. pseudomaculata infestation. We use multiple logistic regression analysis to investigate variations among domiciliary units in terms of the likelihood of being infested by triatomines. 


\section{Material and methods}

\section{Study area}

Field studies were conducted in Curaça, a northern rural municipality (county) in Bahia State devoted to goat and sheep raising and irrigated agriculture. Phytogeographically, the area belongs to the caatinga (scrub forest) region. The study area has three main geographic zones with the following characteristics: (a) irrigated agriculture, near the São Francisco River, (b) livestock raising with altered vegetation due to heavy anthropic pressure, and (c) more preserved vegetation and more scattered human dwellings. In 2000, after three years of negative capture, T. infestans was considered to have been eliminated from Curaça.

From September to November 2002, 136 randomly plotted houses were visited and georeferenced using GPS. Data collection used a standard questionnaire submitted to each household member, a sketched map of each house and peridomiciliary annexes, and an entomological survey (bug capture and analysis). The peridomicile, as defined in this paper, is the yard supporting peridomiciliary structures, regardless of the distance from the main house. Data were computerized as nominal variables (2 to 4 classes) or continuous variables. Environmental data relate to the general situation and spatial organization of the domiciliary unit; demographic data to the number of human inhabitants and synanthropic animals (dogs, livestock, and poultry), sociological data to the origin of the household members, duration of residence, ownership of house (yes/no), head of family retired (yes/no), and use of insecticides (yes/no).

Associations between domiciliary infestation and continuous and nominal variables were first tested by the Mann-Whitney test and Fisher's exact test. Independent variables that were associated with a p-value of $10 \%$ or less were selected for multivariate logistic regression analysis. Variables without significant adjusted effect (likelihood ratio statistic, $p$-value > 0.05 ) were eliminated from the model according to a backward stepwise procedure. Introduction of the previously dropped variables into the most parsimonious model was then tested one-by-one by likelihood ratio statistic. Finally, only significant independent variables ( $\mathrm{p}$-value $<0.05$ ) were kept in the model.

\section{Results}

A total of 395 bugs (73 T. pseudomaculata and 322 T. brasiliensis) were captured, in $50.0 \%$ of the domiciliary units $(68 / 136)$. T. brasiliensis was present in $36.8 \%(50 / 136)$ and T. pseudomaculata in $18.4 \%$ (25/136). T. brasiliensis was mainly captured in corral fences $(31.2 \%$ of the 80 capture sites), piles of tiles or bricks (12.5\%), and chicken coops (10.0\%), as compared to $T$. pseudomaculata in corral fences $(45.9 \%)$ and trees used as chicken roosts $(48.0 \%)$.

Table 1 shows the significant correlations between infested dwellings and descriptive variables. Dwelling infestation rates for T. brasiliensis were positively and significantly associated with mud or adobe houses, number of corrals, mandacaru cactus within a $30 \mathrm{~m}$ radius of the house, and local origin of the household members, and non-significantly with geographic location of the house in the altered vegetation zone. The rates did not increase with numbers of animals, whatever the species. However, the absence of goats and sheep was associated (non-significantly) with low infestation rates in dwellings $(1 / 10,10.0 \%)$, while a herd of 20-99 goats or sheep was associated with a higher infestation rate $(23 / 41,48.8 \%)$.

Dwelling infestation rates with T. pseudomaculata were positively and significantly associated with the geographic location of the house (surroundings with more vegetation), surface area of the domiciliary unit, presence of adobe houses, number of corrals, corral surface area, type of chicken roosts (trees), and headof-household's retirement. The rates increased positively and significantly with the numbers of all synanthropic animals: dogs $(p=0.0003)$, goats or sheep $(p=0.0001)$, cattle $(p=0.0001)$, and poultry $(\mathrm{p}=0.0054)$.

Triatomine infestation (T. brasiliensis and $T$. pseudomaculata combined) was significantly associated with kerosene lamp lighting and solar panel lighting $(\mathrm{p}=0.019)$.

According to multiple logistic regression analysis (Table 2), the likelihood of infestation with $T$. brasiliensis increased with local origin of the household members, presence of goats and sheep, presence of corrals, and presence of mandacaru cactus within a $30 \mathrm{~m}$ radius of the house. The likelihood of T. pseudomaculata infestation increased with the house being located near relatively preserved vegetation, headof-household's retirement, presence of at least two dogs or five cows, and large corrals. 


\section{Table 1}

Environmental and socioeconomic variables associated with Triatoma brasiliensis and Triatoma pseudomaculata infestation.

\begin{tabular}{|c|c|c|c|c|c|c|c|}
\hline \multirow[t]{3}{*}{ Variables } & \multirow{3}{*}{$\begin{array}{c}\text { Number of domiciliary } \\
\text { units visited }\end{array}$} & \multicolumn{6}{|c|}{ Domiciliary unit infestation } \\
\hline & & \multicolumn{3}{|c|}{ Triatoma brasiliensis } & \multicolumn{3}{|c|}{ Triatoma pseudomaculata } \\
\hline & & Number & $\%$ & $p$-value & Number & $\%$ & p-value \\
\hline \multicolumn{8}{|l|}{ Area } \\
\hline Near river & 33 & 9 & 27.27 & 0.152 & 1 & 3.03 & $<0.001$ \\
\hline Altered & 44 & 21 & 47.73 & & 4 & 9.09 & \\
\hline Dense vegetation & 59 & 20 & 33.30 & & 19 & 32.20 & \\
\hline \multicolumn{8}{|c|}{ Surface area of domiciliary unit $\left(\mathrm{m}^{2}\right)$} \\
\hline$<2,000$ & 60 & 19 & 31.66 & 0.456 & 6 & 10.00 & 0.012 \\
\hline $2,000-5,000$ & 59 & 23 & 38.98 & & 12 & 20.33 & \\
\hline$\geq 5,000$ & 17 & 8 & 47.05 & & 7 & 41.17 & \\
\hline \multicolumn{8}{|c|}{ Building material of walls in human dwellings } \\
\hline Mud and wattle & 37 & 16 & 43.24 & 0.011 & 2 & 5.41 & 0.039 \\
\hline Adobe & 53 & 22 & 41.51 & & 14 & 26.42 & \\
\hline Local fired brick & 32 & 12 & 37.50 & & 5 & 15.60 & \\
\hline Modern masonry & 14 & 0 & 0.00 & & 4 & 28.60 & \\
\hline \multicolumn{8}{|l|}{ Number of corrals } \\
\hline 0 & 14 & 3 & 21.42 & 0.0307 & 0 & 0.00 & 0.005 \\
\hline $1-2$ & 45 & 13 & 28.88 & & 3 & 6.66 & \\
\hline $3-4$ & 44 & 15 & 34.09 & & 13 & 29.54 & \\
\hline$\geq 5$ & 33 & 19 & 57.57 & & 9 & 27.27 & \\
\hline \multicolumn{8}{|c|}{ Surface area, corrals $\left(\mathrm{m}^{2}\right)$} \\
\hline$<150$ & 44 & 13 & 29.50 & 0.248 & 3 & 6.80 & 0.009 \\
\hline $150-550$ & 52 & 24 & 46.00 & & 13 & 25.00 & \\
\hline$\geq 550$ & 25 & 10 & 40.00 & & 9 & 36.00 & \\
\hline \multicolumn{8}{|l|}{ Length of fence (m) } \\
\hline$<80$ & 57 & 18 & 31.57 & 0.165 & 4 & 7.01 & 0.0007 \\
\hline $80-200$ & 53 & 23 & 43.39 & & 16 & 30.18 & \\
\hline$\geq 200$ & 10 & 06 & 60.00 & & 5 & 50.00 & \\
\hline \multicolumn{8}{|l|}{ Chicken coops } \\
\hline None & 17 & 7 & 41.18 & 0.366 & 1 & 5.88 & 0.023 \\
\hline Roosts in trees & 92 & 33 & 35.86 & & 23 & 25.00 & \\
\hline Other kind & 25 & 10 & 40.00 & & 1 & 4.00 & \\
\hline \multicolumn{8}{|c|}{ Mandacaru cactus within $30 \mathrm{~m}$ of house } \\
\hline No & 83 & 25 & 30.12 & 0.044 & 14 & 16.86 & 0.568 \\
\hline Yes & 53 & 25 & 47.17 & & 11 & 20.75 & \\
\hline \multicolumn{8}{|c|}{ Head of household retired } \\
\hline No & 77 & 32 & 41.56 & 0.212 & 9 & 11.69 & 0.026 \\
\hline Yes & 59 & 18 & 30.51 & & 16 & 27.12 & \\
\hline
\end{tabular}

Note: Domiciliary unit defined as area encompassing house and outbuildings. 


\section{Discussion and conclusions}

The county of Curaça illustrates an epidemiological situation with: (i) stable population and economic activities, (ii) T. infestans eliminated, and (iii) sylvatic vectors (T. brasiliensis and $T$. pseudomaculata) well-established in peridomiciliary areas. This study confirms previous findings on peridomiciliary habitats of $T$. brasiliensis and T. pseudomaculata 6,7,8 and shows that T. pseudomaculata is more associated with environmental characteristics and animals, while T. brasiliensis is associated with peridomiciliary structures and human activities. Moreover, it suggests some risk factors for domiciliary infestation.

First, the dwelling's type of environment is a risk factor. Domiciliary infestation with $T$. pseudomaculata increases $(\mathrm{OR}=17)$ when the house is built in preserved vegetation where natural ecotopes of the species such as bird nests, tree hollows, and palms 9,10,11 are more numerous. Farmers often mention that the bugs are attracted by light, suggesting a regular flow of sylvatic vectors towards peridomiciliary areas. Dwellings located in areas with altered vegetation and submitted to heavy anthropic pressure are more frequently infested with $T$. brasiliensis. Mandacaru, a cactus grown around farms to complement livestock feed, is an indicator of an active livestock activity in an impoverished environment. It is also significantly associated with $T$. brasiliensis infestation.

Second, human activities play an important role in domiciliary infestation. Origin, age, and retirement of household members were included as possible indicators of the farm families' general way of life. They are associated with $T$. brasiliensis and T. pseudomaculata infestation, probably through different activities and different ways of managing peridomiciliary areas and animals.

Third, the results suggest that presence of livestock produces numerous interconnected risk factors for triatomine infestation. Corrals and livestock are strongly correlated with infestation of human dwellings. It is thus probable that the general conditions under which livestock are raised should be better researched and improved to obtain optimum triatomine control.

In this context, where adaptation of vectors to the natural environment and human activities has occurred for a long time, triatomine infestation of human dwellings is obviously a multi-factor process which should to be studied as such.
Odds ratio between infestation of domiciliary unit with Triatoma brasiliensis or Triatoma pseudomaculata and socioeconomic, environmental, and demographic variables (multivariate analysis).

\begin{tabular}{|c|c|c|c|}
\hline Species & Odds ratio & $95 \% \mathrm{Cl}$ & p-value \\
\hline \multicolumn{4}{|l|}{ Triatoma brasiliensis } \\
\hline \multicolumn{4}{|c|}{ Origin of household members } \\
\hline Other municipality & 1.0 & - & 0.005 \\
\hline Same municipality & 4.4 & $1.6-12.5$ & \\
\hline \multicolumn{4}{|l|}{ Goat/sheep } \\
\hline Absence & 1.0 & & 0.008 \\
\hline$<100$ & 13.2 & $1.1-167.9$ & \\
\hline$\geq 100$ & 3.2 & $0.3-39.7$ & \\
\hline \multicolumn{4}{|l|}{ Corrals } \\
\hline No & 1.0 & & $<0.001$ \\
\hline Yes & 3.1 & $1.1-8.3$ & \\
\hline \multicolumn{4}{|c|}{ Mandacaru cactus within $30 \mathrm{~m}$ of house } \\
\hline No & 1.0 & & 0.050 \\
\hline Yes & 2.2 & $1.1-8.3$ & \\
\hline \multicolumn{4}{|l|}{ Triatoma pseudomaculata } \\
\hline \multicolumn{4}{|l|}{ Geographic area } \\
\hline River and altered & 1.0 & & $<0.001$ \\
\hline More dense vegetation & 17.1 & $3.9-75.6$ & \\
\hline \multicolumn{4}{|l|}{ Head of household retired } \\
\hline No & 1.0 & & 0.008 \\
\hline Yes & 5.8 & $1.6-21.4$ & \\
\hline \multicolumn{4}{|l|}{ Dogs } \\
\hline$<2$ & 1.0 & & 0.002 \\
\hline$\geq 2$ & 12.8 & $2.6-63.3$ & \\
\hline \multicolumn{4}{|l|}{ Cattle } \\
\hline$<5$ & 1.0 & & 0.014 \\
\hline$\geq 5$ & 6.0 & $1.4-24.8$ & \\
\hline Corral surface area $\left(\mathrm{m}^{2}\right)$ & 1.0024 & $1.0002-1.0046$ & 0.030 \\
\hline
\end{tabular}




\section{Resumo}

O objetivo deste estudo foi o de explorar (em Curaçá, município do Estado da Bahia, no Nordeste brasileiro) os possíveis fatores associados à infestação das moradias pelo Triatoma brasiliensis ou Triatoma pseudomaculata, dois triatomas das espécies silvestres. Usamos uma análise "logística" de múltipla regressão para mostrar como as características estruturais da área do peridomicílio associadas ao número de animais e a fatores sociológicos favorecem a infestação em algumas moradias. Isso sugere que $\mathrm{T}$. brasilienses está associado às atividades humanas enquanto T. pseudomaculata está associado à vegetação e aos animais. Assim, o manejo da pecuária é um importante fator de risco para a infestação de triatomíneos.

Triatominae; Fatores de Risco; Controle de Vetores.

\section{Contributors}

A. Walter, I. Pojo do Rego, A. Ferreira and C. Rogier participated in the overall study concept and design, data collection, data analysis, and drafting of the paper.

\section{Acknowledgments}

This study is a part of a wider research project (Landscape ecology, dynamics of agro-ecosystems, and eco-pathogen complexes: definition of eco-epidemiological risk in the case of American trypanosomiasis) developed under CNPq-Fiocruz/IRD cooperation (Project no. 910157/00-6) and coordinated by Laure Emperaire (IRD) and Ana-Maria Jansen (Fiocruz). It has received full support from the Center for Sustainable Development (CDS), Brazilian National Health Foundation (FUNASA), (15 th Regional Health Office in Juazeiro and Curaça), and has obtained research approval from the FIOCRUZ Institutional Review Board/Ethics Committee (no. 187/023) and the Brazilian Environmental Institute, IBAMA (no. 137/2003CGFAU/LIC). Laure Emperaire and Dori Sayago participated actively in the preliminary survey. Ana-Maria Jansen and Christina Romaña analyzed the triatomines. Triatomine captures were conducted by the FUNASA team in Curaça.

\section{References}

1. Dias JC. Controle de vetores da doença de Chagas no Brasil e riscos da reinvasão domiciliar por vetores secundários. Mem Inst Oswaldo Cruz 1988; 83 Suppl 1:387-91.

2. Diotaiuti L, Faria Filho OF, Carneiro FC, PintoDias JC, Pires HH, Schofield CJ. Aspectos operacionais do controle do Triatoma brasiliensis. Cad Saúde Pública 2000; 16 Suppl 2:61-7.

3. Lucena D. Ecologia dos triatomineos do Brasil. Rev Bras Malariol Doenças Trop 1959; 11:577-635.

4. Lucena D. Doença de Chagas no nordeste. Rev Bras Malariol Doenças Trop 1959; 11:675-96.

5. Costa J, Almeidan JR, Britton C, Duarte R, Marchon-Silva V, Pacheco RD. Ecotopes, natural infection and trophic resources of Triatoma brasiliensis (Hemiptera, Reduviidae, Triatominae). Mem Inst Oswaldo Cruz 1998; 93:7-13.

6. Oliveira-Lima JW, Faria Filho OF, Furtado-Vieira JB, Vieira-Gadelha F, Oliveira Filho AM. Alterações do peridomicílio e suas implicações para o controle do Triatoma brasiliensis. Cad Saúde Pública 2000; 16 Suppl 2:75-81.

7. Silveira AC, Costa-Vinhaes M, Lira E, Araujo E. O controle de Triatoma brasiliensis e Triatoma pseudomaculata. II. Avaliação do controle físico, pela melhoria habitacional, e caracterização do ambiente peridomiciliar mais e menos favorável à persistência da infestação ou reinfestação por Triatoma brasiliensis e Triatoma pseudomaculata. Brasília: Organização Pan-Americana da Saúde; 1998.

8. Torquato GN, Santos CC, Mendonça MB, Carvalho SM, Kido EA, Santos ES, et al. Eco-epidemiology of Chagas disease in Pernambuco: I. present role of wild triatomines in the transmission of Trypanosoma cruzi. Mem Inst Oswaldo Cruz 1998; 93 Suppl 2:331.

9. Alencar JE. História natural da doença de Chagas no Estado do Ceará. Fortaleza: Imprensa Universitária, Universidade Federal do Ceará; 1987.

10. Bento ON, Freitas MR, Pinto A. Epidemiologia da doença de Chagas nos municípios de Castelo do Piaui e Pedro II, Estado do Piauí, Brasil. Rev Bras Malariol Doenças Trop 1989; 22:73-9.

11. Mello DA. Aspectos do ciclo silvestre do T. cruzi em regiões de cerrado (município de Formosa, Estado de Goiás). Mem Inst Oswaldo Cruz 1981; 76:227-46

Submitted on 26/May/2004

Final version resubmitted on $22 /$ Oct $/ 2004$

Approved on 04/Nov/2004 